\title{
LAST YEAR UNIVERSITY STUDENTS' MOTIVES FOR LEARNING AND THE WAYS TO INCREASE THEIR MOTIVATION
}

\author{
Jelena Jermolajeva \\ EKA University of Applied Sciences, Latvia \\ Svetlana Silchenkova \\ Smolensk State University, Russian Federation \\ Larissa Turusheva \\ EKA University of Applied Sciences, Latvia
}

\begin{abstract}
Monitoring and analysing the students' academic motivation allows the university teacher to look at the results of her/his work from another aspect and reflect on the ways of increasing the effectiveness of teaching. The aim of the study is to analyse and compare the groups of the learning motives of last year students at the Universities of Riga (EKA University of Applied Sciences) and Smolensk (Smolensk State University), on the basis of which propose the ways to increase their motivation. In the international survey, which was carried out in December 2018 - June 2019, 101 students participated. Descriptive statistics was used for the data processing. Data analysis shows that in both samples the group of professional motives plays a leading role in the students' learning motivation. In Latvia, the second and third places are to communication and creative self-realisation motives, in the Smolensk sample - social and communication motives, respectively. The results of the study can be used by university teachers and study programme directors for improving the management of education and raising the quality of the pedagogical process.
\end{abstract}

Keywords: avoidance motives, communication motives, creative self-realisation motives, educational-cognitive motives, prestige motives, professional motives, social motives, students' learning motivation.

\section{Introduction}

The motivation of students plays a significant role in the success of their learning. There are many types of classification of motives that complement each other and are closely connected. In relation to the individual, the motivation can be classified as internal (more conscious, aimed at achieving the individual goal) and external (influenced by other people or other sources); by direction, it can be positive and negative; by the level - strong, weak or average; by the areas of activity - professional, educational, creative, communicative, etc. (Richard, 2019; Il’in, 2002; Cofer \& Appley, 1964). 
For good results of learning activities, the internal positive motivation of students aimed at the educational process is important (Veliverronena \& Grinfelde, 2019; Šteinberga, 2013). As practice shows, not all students have a high level of motivation; the teacher's task is to raise it. The problem of lack of motivation in students has many facets. Weak academic motivation leads to a decrease in academic performance, and the dropout of students. In recent decades, there has been an increase in the number of new students enrolling in universities who are psychologically, socially and academically unprepared for higher school: they show inappropriate behaviour such as being late for class, alienation attitude to teachers and administration of the university, unrealistic expectation of high grades, and others (Howey, 2008). In this case, the only thing that can keep a student at the university is increasing their motivation. According to D. Kelly, "When students have both a lack of academic skills and lack motivation, the greater problem is motivation" (Kelly, 1988). However, even the students who are well prepared to study at the university do not sometimes reach a high level of knowledge and competence in case of lack of motivation.

Working on student motivation increase is essential for the well-being of both students and academic staff, as well as the society as a whole (Korb, 2014). A comprehensive study of academic motivation, including both external and internal factors influencing students' academic activity, is a prerequisite for the effectiveness of this work.

This article presents the results of the pilot phase of the Russian-Latvian research project on the academic motivation of university students. At this stage the academic motivation of graduate students has been studied. They were asked to assess (in fact, already retrospectively) the impact of different motives on their learning activities. The study results allow teachers who have worked with these students for several years, to look in detail at the motivational aspect of their learning-teaching collaboration, and to reflect on the ways of increasing students' motivation.

The aim of this study is to analyse and compare the groups of the learning motives of graduate students at the universities of Riga (EKA University of Applied Sciences) and Smolensk (Smolensk State University), and propose the ways of increasing their motivation.

\section{Methodology}

The following methods are used in the empirical study: survey, organisation of data using descriptive statistics, analysis of statistics. The study is based on the technique "Diagnostics of educational motivation of students" by N. Badmayeva (Badmayeva, 2004), which makes it possible to determine the overall level of learning motivation and the level of motivation for separate groups of motives. In 
this method, the motives are grouped into blocks by the types of activities of students:

- Communication motives show the willingness and readiness of students to communicate with fellow students and teachers.

- Motives of avoidance indicate the intention to keep up with fellow students in their learning activities and to avoid condemnation.

- $\quad$ The motives of prestige demonstrate the desire of students to be the best in everything.

- Professional motives show the desire to master professional competences.

- The motives of creative self-realization correspond to the desire to creatively prove themselves and realize their talents.

- Educational-cognitive motives show the desire to gain knowledge.

- Social motives show the desire to be in demand in society and make a useful contribution to it.

There are 34 statements in the questionnaire all together. Each group (block) of motives contains several statements (from 2 to 7), which are not organised by blocks, but are scattered throughout the questionnaire. Respondents are asked to evaluate each of the statements on a 5-point system: 1 point means the minimum value of the motive, 5 points - the maximum. The following scale is used to determine motivation levels:

1 to 2.3 points is a low level of motivation,

2.4 to 3.6 points is the average one,

3.7 to 5 points is a high level of motivation.

101 graduates took part in the survey. The survey of students at Smolensk State University (further - SmolSU) was conducted in December 2018 among the students of economic specialties and future managers; 56 people were surveyed. In June 2019, 45 Riga students graduating from the EKA University of Applied Sciences (EKA) in economics, management, law and translation programmes were surveyed. The average age of Riga respondents is 25, Smolensk ones -22 . The number of females in the Riga and Smolensk samples exceeds the number of males in accordance with the gender proportion of students of these universities: in the Riga sample there are 35 females (77.8\%), in the Smolensk sample $33(58.9 \%)$.

\section{Research Results}

For the data of each of the two samples, Cronbach's Alfa coefficient was calculated; it is 0.99 for the Riga questionnaire and 0.95 for Smolensk. The high value of the indicator shows a sufficient reliability of the technique. 
Averages for seven groups of motivation are shown in the chart (Fig.1). As can be seen from it, the motivation levels of Riga and Smolensk students are somewhat different. Riga students showed higher scores on five groups of motives (communicative, professional, educational-cognitive, creative, prestige motives); Smolensk graduates are ahead on two types of motivation (social motives, motives of avoidance). The average for all 34 motives is 3.08 in the Riga sample and 2.81 in Smolensk one; both indicators correspond to the average level of motivation.

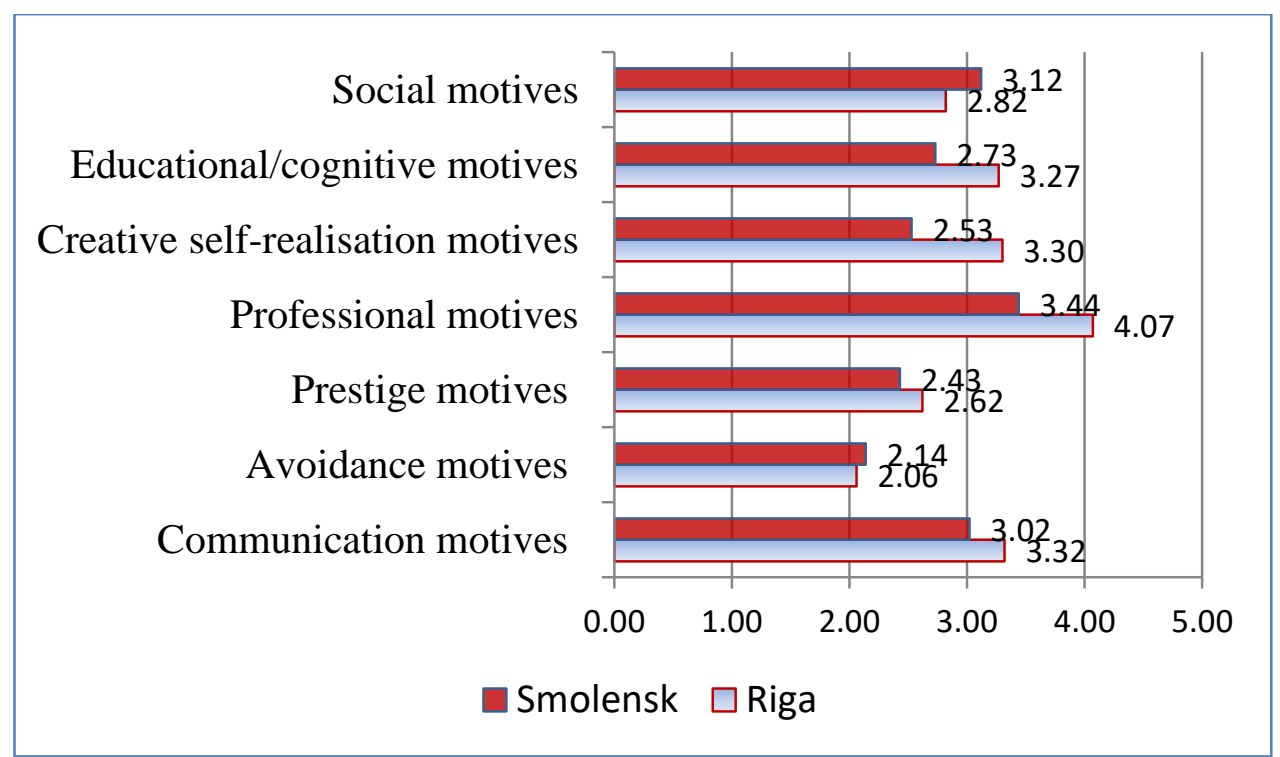

Figure 1 Learning motivation of students of Riga and Smolensk: average values by groups of motives

To analyse students' motivation, it is also necessary to consider other descriptive statistics indicators for two samples: mode, dispersion, and coefficient of variation $(\mathrm{CoV})$. These indicators for the groups of motives, as well as the total for all 34 statements, are given in Table 1.

Table 1 Statistical indicators of the learning motivation of students of Riga and Smolensk by groups of motives and in general on the questionnaire

\begin{tabular}{|l|c|c|c|c|c|c|}
\hline \multirow{2}{*}{$\begin{array}{c}\text { Group of learning } \\
\text { motivation }\end{array}$} & \multicolumn{3}{|c|}{ EKA } & \multicolumn{3}{c|}{ SmolSU } \\
\cline { 2 - 7 } & Mode & Dispersion & $\begin{array}{c}\text { CoV } \\
(\%)\end{array}$ & Mode & Dispersion & $\begin{array}{c}\text { CoV } \\
(\%)\end{array}$ \\
\hline Communication motives & 4 & 1.01 & 30.31 & 3 & 1.56 & 41.27 \\
\hline Avoidance motives & 1 & 1.48 & 59.02 & 1 & 1.38 & 54.99 \\
\hline Motives of prestige & 3 & 0.92 & 36.52 & 1 & 1.53 & 50.85 \\
\hline
\end{tabular}


SOCIETY. INTEGRATION. EDUCATION

Proceedings of the International Scientific Conference. Volume I, May $22^{\text {th }}-23^{\text {th }}$, 2020. 266-275

\begin{tabular}{|l|c|c|c|c|c|c|}
\hline Professional motives & 4 & 0.54 & 18.03 & 4 & 1.5 & 35.57 \\
\hline $\begin{array}{l}\text { Creative self-realisation } \\
\text { motives }\end{array}$ & 3 & 0.68 & 25.07 & 3 & 1.3 & 45.06 \\
\hline $\begin{array}{l}\text { Educational-cognitive } \\
\text { motives }\end{array}$ & 3 & 0.96 & 29.89 & 3 & 1.58 & 46.05 \\
\hline Social motives & 3 & 0.79 & 31.51 & 3 & 1.88 & 43.98 \\
\hline $\begin{array}{c}\text { Indicators on the } \\
\text { questionnaire as a whole }\end{array}$ & 3 & 1.3 & 37.01 & 3 & 1.73 & 46.95 \\
\hline
\end{tabular}

In general on the questionnaire, the mode (i.e. the most common score) in two samples is three, which corresponds to the average level of motivation. At the same time, however, there is a large variance of responses in both national samples. The coefficients of variation on the questionnaire as a whole are greater than 33\%, which indicates a large discrepancy of answers and atypical averages. Analysis of the coefficients of variation by the groups of motives shows that in the Riga sample the average arithmetic value cannot be called typical in two groups (motives of avoidance and motives of prestige), while in Smolensk sample too great discrepancy of answers is observed in all groups of motives. There is also a difference between the two samples in the consistency of answers on separate questions. In the Smolensk sample data, the coefficients of variation more than 33 per cent are in most items. Only 5 of 34 questions received wellagreed rates; four of them belong to the group of professional motives, one - to the group of educational-cognitive motives. The Riga sample has well agreed rates on 23 items.

The following is a more detailed analysis of the obtained data by the groups of motivation.

Communication motives are formed in students at the middle level. The average arithmetic values for this group of motives are 3.32 in Riga and 3.02 in Smolensk (however, a large variation of opinions in the Russian sample should be taken into account). Students believe that knowledge will enable them to better communicate with people, including the future colleagues. This motive has received the highest rating in the group; its mode is 4 in both samples. Graduates also believe that knowledge is necessary for getting acquainted and communicating with interesting people (mode 3), gives self-confidence (mode 4 in Riga and 3 in Smolensk). The statement "I want to be respected in the student group" has the lowest rate of all the communication motives: $50 \%$ of Smolensk students and $62 \%$ of Riga students rated it with 1-2 points. For this item the lowest average values are observed (2.27 in Riga and 2.52 in Smolensk), as well as the lowest mode ( 2 and 3 , respectively). Thus, at the very end of the university course the graduates do not consider the respect of the student community an important motivating factor for learning. 
The motives of avoidance received minimal points (a low level of formation). This is a positive result: students learn not because they want to impress their relatives or friends, they do not care about condemnation for poor studies, either; i.e. they study not for someone, but for themselves. A large variability of responses, however, suggests different assessments of this group of motives. The averages for the block are 2.06 in Riga and 2.14 in Smolensk, the mode is 1 . A number of graduates assess the motives of avoidance by 4-5 points, the majority of such students are in SmolSU. For example, the statement "I am learning to avoid condemnation and punishment for poor studies" Riga students rated only by 1-2 points, Smolensk students - by 1-4 points.

Respondents' assessment of prestige motives is at an average level (group rating in Smolensk sample is 2.43, in Riga - 2.62). It is noteworthy that it is not so important for graduates to be the best; they do not think it is important for the student community, either. Only 2 students from Riga gave score 5 to the statement "I want to be the best student", most of them rated the statement by 3 points; it is enough for them to be average students. In the Smolensk sample, none of the students put 5 points to this statement; most of them rated it by 2 points. It does not matter for students to be in good standing with teachers (mode is 2 points), the opinion of parents is more valuable for them (mode is 3). Good grades in the diploma are important for $18 \%$ of Riga students and for $41 \%$ of Smolensk students. It can be assumed that the students of Riga are somewhat more honest with themselves; they do not care much not only about internal prestige motives, but also about external ones.

Professional motives received the highest scores in both samples. In the Riga sample, the average for professional motives is 4.07 (high level of motivation), in Smolensk - 3.44 (average level). It is noteworthy that in this group of motives the least variability has been observed as well: the coefficient of variation is $18.03 \%$ and $35.57 \%$, respectively. Most students after graduation want to become specialists in their profession and achieve success in it. However, there are students from the Smolensk sample do not like the chosen profession: 18\% of Smolensk graduates rated their motivation on this issue by 1-2 points. Apparently, they got disillusioned with the profession during their studies, or initially enrolled more by necessity than at will.

The motives for creative self-realization are formed among graduates at the average level (the group's rating is 3.3 in the Latvian sample and 2.53 in the Russian one) and are more important for Riga students than for Smolensk ones. Most students want to use creative approach in their professional activities in the future, to give answers to the problems of social development and life of people.

Educational-cognitive motives are also at the average level; they are slightly higher with Riga students. In both samples, the most common score for this motivation block is 3 points. Most Riga and Smolensk students like to be ready 
for classes, to acquire knowledge, as it can be useful in the future. However, only a minority of students seek to get high grades: $30 \%$ of Russian respondents, and only $7 \%$ of Latvian respondents. This fact shows once again that the Smolensk students are more eager than Riga's ones to develop an external manifestation of success. The answers of Riga students on this block of questions are relatively well-agreed (coefficient of variation is $29.89 \%$ ), while the answers of Smolensk graduates are contradictory (coefficient of variation is $46.05 \%$ ).

The rating of learning motivation groups is closed by social motives, although their level of formation is average, too. The average rate of this group of motives in the Smolensk sample is higher than in Riga (3.12 vs. 2.82). The greatest difference between the data of the two samples is observed in the issues of future career and material well-being dependence on university studies. In the Smolensk sample, the majority of students believe that their future financial security (53.6\% of scores 4 or 5 ) and their official position (55\%) depend on academic success. Riga students do not see a direct relationship between academic success and material well-being and career, most of them rated the corresponding statements by 3 points.

When ranking the groups of motives in two samples, the following table (Table 2) is obtained:

Table 2 Ranking of motive groups

\begin{tabular}{|l|l|l|}
\hline Rank & \multicolumn{1}{|c|}{ EKA } & \multicolumn{1}{c|}{ SmolSU } \\
\hline 1 & Professional motives & Professional motives \\
\hline 2 & Communication motives & Social motives \\
\hline 3 & Creative self-realisation motives & Communication motives \\
\hline 4 & Educational-cognitive motives & Educational-cognitive motives \\
\hline 5 & Social motives & Creative self-realisation motives \\
\hline 6 & Motives of prestige & Motives of prestige \\
\hline 7 & Avoidance motives & Avoidance motives \\
\hline
\end{tabular}

In both samples, the first place is occupied by professional motives; that means that students learn, first of all, to become good professionals. The last two places are occupied by the motives of prestige and avoidance. In the fourth place there are educational-cognitive motives. The remaining ranks are different for the two samples. Social motives are in the second place for Smolensk students: students also study to take a certain place in society. EKA students put social motives in the fifth place, which indicates a more internal, compared to Smolensk graduates, focus of motivation; external manifestations (e.g. high positions) are not so important for them. It may also indicate a certain indifference to the public request. 
It is noteworthy that educational-cognitive motives took only the fourth place; that is, students do not consider them to be of paramount importance for the future profession. They want to become good specialists, but it is not necessary to study well.

Students of Riga are more creative in their studies, which can be explained in part by the peculiarity of the university in which they study. The original Latvian name of the university, which is included in the form of the abbreviation EKA in the official English name, is "Ekonomikas un Kultūras Augstskola”, i.e. "University College of Economics and Culture". EKA maintains some humanitarian and artistic bias and in addition to "hard" areas of study offers also "soft" study programmes such as "Translation," "Culture Management," "Management of Entertainment Industry”, "Interior Design”, “Computer Games Design and Graphics". Joint training with representatives of humanitarian and creative professions affects the general atmosphere of the university and contributes to the promoting creativity.

The study has shown that in general the motivation of students of SmolSU and EKA is at an average level. However, it can and should be raised. The results of the study can be used by university teachers and study programme directors for raising the quality of the pedagogical process and improving the management of education.

The main ways to increase motivation can be:

1. Bigger variety of study forms, increasing the number of colloquiums, seminars, workshops, projects, stimulating creative search. Modern classes should be more integrated with other subjects and with profession.

2. The convergence of educational material with the specifics of real profession. There should be a sufficient number of laboratories and specialized centres for classes; they must be zoned, equipped with special equipment and software.

3. Improving the students' assessment system. It should be objective, differentiated, reducing student stress during the examination session.

At the next stage of the research project, it is planned to monitor and analyse the academic motivation of students of the first and last year, as well as to analyse the correlation of motivation with the psychological atmosphere in student groups. It is also planned to expand research base by including participants from other countries in the project. 


\section{Conclusions}

The data of the two samples show that in general, the students of Smolensk and Riga have the average level of learning motivation. Out of 7 groups of learning motives, professional motives are dominating; that is, the main goal of the students' studying is to become good specialists in the chosen profession. In Latvia, the second and third places are to communication and creative selfrealisation motives, in the Smolensk sample - social and communication motives, respectively. Students of Riga and Smolensk do not see a direct relationship between successful studies and professional competence; this is especially evident in the Riga sample.

The motivation of Smolensk respondents is generally slightly lower than that of Riga ones. This can be explained by the younger age of the Smolensk students (in the Russian school they study not 12, but 11 years), the smaller choice of higher education institutions in Smolensk, a large number of young men in the sample (some of them go to the university to get postponement from the compulsory military service).

To increase the academic motivation of students, it is proposed to use more widely a variety of forms of classes that stimulate independent creative search, to bring the educational material closer to the specifics of real profession, improve the system of students' assessment.

\section{Acknowledgement}

This paper has been funded by the EKA University of Applied Sciences (Riga, Latvia).

\section{References}

Badmayeva, N. Ts. (2004). Vliyanie motivacionnogo faktora na razvitie umstvennyx sposobnostej [The influence of motivational factor on the development of mental abilities]. UlanUde: Publishing Hous VSGTU. (in Russian)

Cofer, C.N., \& Appley, M.H. (1964). Motivation: Theory and research. New York: John Wiley. Howey, S.C. (2008). Factors in student motivation. Academic Advising Resources of the National Academic Advising Association (NACADA). Retrieved from https://nacada.ksu.edu/Resources/Clearinghouse/View-Articles/Motivation.aspx

Il'in, E.P. (2002). Motivacija i motivy [Motivation and motives]. St. Petersburg: Piter. (in Russian)

Kelly, D.K. (1988). Motivating the underprepared unmotivated community college student. California: Fullerton College. Retrieved from https://files.eric.ed.gov/fulltext/ED299009.pdf

Korb, K. A. (2014). Motivation in education: Beyond salary, benefits, and welfare. Journal of Educational Foundations, 4, 1-8. 
Jermolajeva et al., 2020. Last Year University Students' Motives for Learning and the Ways to Increase their Motivation

Richard, R. (Ed.) (2019). The Oxford Handbook of Human Motivation (2 ${ }^{\text {nd }}$ ed.). Oxford: Oxford University Press.

Šteinberga, A. (2013). Pedagogiskā psihologija [Pedagogical psychology]. Rīga: RaKa. (in Latvian).

Veliverronena, L., \& Grinfelde, I. (2019). Who is guilty that I fail in classroom: students' perspective on higher education. Society, Integration, Education, I, 594-606. DOI: 10.17770/sie2019vol1.3841 